\title{
DEVELOPING PLANT TOLERANCE INDICATOR TO AIR POLLUTION, CASE STUDY IN KRAKATAU INDUSTRIAL ESTATE CILEGON CITY, INDONESIA
}

\author{
Desi Anjana Dwiputri \\ Department of Landscape Architecture, \\ Graduate School, Bogor Agricultural \\ University, Dramaga Campus, Bogor 16680, \\ Indonesia. \\ Email : $\underline{\text { desiadwiputri@ymail.com }}$
}

\section{Nizar Nasrullah}

Department of Landscape Architecture, Faculty of Agriculture, Bogor Agricultural University, Dramaga Campus, Bogor 16680, Indonesia

\section{Zainal Alim Mas'ud}

Department of Chemistry, Faculty of Mathematics and Natural Sciences, Bogor

Agricultural University, Dramaga Campus, Bogor 16680, Indonesia

\begin{abstract}
Plant tolerance against air pollutants from industrial estate can be assessed based on the change of physiological parameters calculated according to APTI (Air Pollution Tolerance Index by Singh). However, based on previous research, APTI formulation was less accurate, the results obtained between macroscopic and physiological observations are not always sync. Additional physiological parameters, i.e. total carbohydrates as main product of photosynthesis process was need to be examined. Therefore, purpose of this study were to examine the physiological parameters that indicate the level of tolerance of plants sensitivity to air pollution and to analyze the level of tolerance of tree species to air pollution in industrial estate. The method used in this research were survey method, along with macroscopic parameters (leaf area, leaf number, and leaf hue), microscopic parameters (stomatal density, leaf and palisade thickness) and physiological parameters (ascorbic acid content, total chlorophyll, leaf $\mathrm{pH}$, water content, and total carbohydrate) observation of tree species which exposed to pollution and non-pollution (control). The results of this research showed that total carbohydrate as an additional parameter affected the level of tolerance by $49.2 \%$ and thus modified the APTI formulation and changed the classification range of plants tolerance. Results showed that the tolerant plants were Polyalthia longifolia Sonn., Polyalthia fragrans (Dalzell) Hook. f. E Thomson, Erythrina crista-galli L., and Casuarina junghuhniana Miq.; moderate tolerance were Hibiscus tiliaceus L., Samanea saman (Jacq.)Merr. and Acacia auriculiformis A. Cunn. ex Benth; and intolerant were Leucaena leucocephala (Lam.) de Wit, Pterocarpus indicus Wild., and Swietenia mahagoni L.
\end{abstract}

Keywords: Air Pollution Tolerance Index, modified APTI, industrial plants, relative growth rate, total carbohydrate.

\section{INTRODUCTION}

Cilegon City is one of the industrial cities in Indonesia and became an industrial estate in West Banten areas. The potential of environmental degradation was occured in the industrial estate of Cilegon, as observed from the indication of an inappropriate land convertion, the decreasing of open green space, as well as the decreasing of the environment quality as a result of potensial industrial waste pollution that exceeded the quality standard in the industrial estates in Cilegon City. According to Rahmat (2014) air condition in Ciwandan Subdistrict of Cilegon city that located directly to Krakatau Industrial Estate Cilegon cause the increasing number of people suffering the Under Respiratory Infection (URI). This matter indicated that the poor air quality in industrial estates was caused by the air pollution.

Green open space was an alternative to diminish air pollution. Besides the effectivenes of reducing pollution, plants tolerance to air pollutant was one the important factors to determined trees type as a green space element. If the plants was tollerant to air pollution then its function as an agent to diminish air pollution can work well by also keep maintaining the optimum growth and development of the plants. Plants tolerance level to pollution as a result of parameter alteration, commonly measured and correlated with plants response level (Bora and Joshi, 2014). Plants response to stress was divided into three levels, i.e growth, physiology, and molecular (Oguntimehin et al., 2010). Therefore the species tolerance level of some trees to air pollution has to be examined macroscopically, microscopically, and physiologically.
Air Pollution Tolerance Index (APTI) was used by landscape expert as one of the selection criterias to determined the type of plants that were tollerance to air pollution (Liu and Ding, 2007 Rai, 2013). However, this APTI method had a weakness, which was the unsynchronized result beetwen macroscopic and physiological observations (Sulitijorini et al., 2008). It means, the formula was not fully compatible with some types of plants. Therefore, additional parameter that affected tree's growth in physiological observation, i.e total carbohydrate content in plants, needs to be investigated. Total carbohydrate content needs to be investigated because this was the main product of photosyntetic process. With the addition of total carbohydrate parameter in this physiological observation, a more accurate tolerance level would be obtainaed as a reference to determined the type of plants that are tolerant to air pollution.

Therefore, purpose of this study were to examine the physiological parameters that indicate the level of tolerance of plants sensitivity to air pollution and to analyze the level of tolerance of tree species to air pollution in industrial estate.

\section{MATERIALS AND METHODS}

The experiment was conducted in industrial estate of PT Krakatau Industrial Estate Cilegon (KIEC), Cilegon city, Banten, Indonesia. Geographycally located at $2{ }^{\circ} 30^{\prime}-20^{\circ} 05^{\prime}$ EL and $27^{\circ} 15^{\prime}-$ 50॰15 ‘ SL. The research was carried out from April to June 2015. The research was done by several stages: 


\section{DWIPUTRI, NASRULLAH, MAS'UD}

\section{Survey}

Field survey was done to specified the location, species of trees, and location of specimen. Sampling was carried out in two locations, which were in polluted area and non-polluted area (control). Pollution-exposed sample was carried from the areas that had highest pollution level, and as comparison, the nonpollution sample was takenfrom low pollution level areas which were resident districs, hotel districs, and golf area.

Location of sample tress was determined by the distribution of pollutant. The highest pollution-exposed trees based on KIEC (2014) was chosen as the sample tree species. Furthermore, the chosen sample tree was a tree with a height of $\geq 3 \mathrm{~m}$ above ground level and leaves position were on the outer canopy to make sure that the leaves taken were exposed to pollution. On every sample tree, the branch was chosen randomly, and leaves taken were on $\pm 10-15 \mathrm{~cm}$ from the tip of the branch. Samples were taken from 10 different trees species which were Acacia auriculiformis A. Cunn. ex Benth, Pterocarpus indicus Wild., Casuarina junghuhniana Miq., Erythrina crista-galli L., Polyalthia fragrans (Dalzell) Hook. f. \& Thomson, Polyalthia longifolia Sonn., Leucaena leucocephala (Lam.) de Wit, Swietenia mahagoni (L.) Jacq, Samanea saman (Jacq.) Merr., and Hibiscus tiliaceus L. The macroscopic, microscopic, and physiological observation was done to every trees species with three replications on every sample and parameter.

\section{Data collection}

a. Macroscopic observation. The observation was measuring the growth of each tree species in 2 months, from April to June 2015. Parameters observed was leaf area, leaf number, and leaf hue.

- Leaf area was determined by copied the leaf sample, except for coniferous trees, measurements was not done. Further measurement was done to the same leaf sample that was added with the newly formed leaves. Measurement was done by the tranparent plotting paper photography method (Nugraha AN, 2013). Leaf surface was affixed to a board, plotting paper was set above the leaf and then photographed. Leaf area was determined based on the number of boxes in the leaf pattern, with calculation as follow:

$$
\text { Leaf area }=n \times L k
$$

Annotation :

$$
\mathrm{n}=\text { number of boxes } \quad \text { Lk = wide of each box }
$$

Measurement of box wide (Lk) used had an accuracy of 1 $\mathrm{cm}^{2}$ (box size $1 \mathrm{~cm} \times 1 \mathrm{~cm}$ ). Boxes that cover up the leaf pattern included to the calculation if it were covered the leaf $>0.5$ of size reference, or equal to $0.5 \mathrm{~cm}^{2}$.
- Parameter of leaf number was observed in every whole sample tree at each observation time. Leaves calculated was the leaves unfolded.

- The quality of hue rendition assesed from leaf hue that accordant to hues in Munsell Color Chart for Marketing and Merchandising with various score levels and notations (Table 1). Leaf hue measurement was not compared beetwen species because the hue standard used to them was different. Comparison done beetwen polluted-exposed and control leaves in every species.

\begin{tabular}{|c|c|c|}
\hline $\begin{array}{l}\text { Hue } \\
\text { score }\end{array}$ & Leaf hue & Notation \\
\hline 1 & Yellow & 2.5 Y L1 \\
\hline 2 & Green yellow & 2.5 GY DL4 \\
\hline 3 & Light green & 5 GY DL4 \\
\hline 4 & Green & 2.5 G DL1 \\
\hline 5 & Dark green & $2.5 \mathrm{G} \mathrm{DL} 2$ \\
\hline 6 & Very dark green & $2.5 \mathrm{G} \mathrm{DK} 1$ \\
\hline
\end{tabular}

Tabel 1. Score, color, and notation

b. Microscopic observation. Microscopic observations consist of specimen preparation with paradermal incision to observed air pollution effect to stomatal density and transversal incision to observed leaf and palisade thickness as well as the damage on the leaf tissue (Udayana, 2004). Paradermal incision was made by whole mount method (Sass, 1951) while transversal incision was made by frozen mikrotom method.

c. Physiological observation. Physiological observationof the leaf were included the analysis of ascorbic acid content, total chlorophyll, leaf $\mathrm{pH}$, relative water content, and total carbohydrate content. Sampling of fresh leaves was done in the morning beetwen 07.00 to 08.00 am (Salama et al., 2011). Leaf samples were taken from the elevation of 1-2 $\mathrm{m}$ from ground level and then taken to the laboratory in the plastic wrap, and stored in the ice box for further analysis (Rai, 2013). Ascorbic acid content was determined by the modification method developed by Reiss (1993). Total leaf chlorophyll (mg g-1) determined by visible light spectrophotometry method (Arnon, 1949). Acidity (pH) of leaves extract was measured by $\mathrm{pH}$ meter (Singh and Rao, 1983). Relative water content, that showed the water content percentage in the leaf, was determined by ovenmethod (Sen and Bhandari, 1978). Measurement of total carbohydrate content was determined by phenolsulphuric acid method (Masukoet al., 2005). 
d. Atmospheric (air) sampling. Measurement of ambient air consentration comprises the $\mathrm{NO}_{2}, \mathrm{NH}_{3}, \mathrm{H}_{2} \mathrm{~S}$, and $\mathrm{SO}_{2}$ gasses, dust, ozone, and hydrocarbon. Measurement was carried out in two spots, which were in the pollution exposed area in the industrial district and non-pollution area (control) in the resident districs in the morning for two hourson June $6^{\text {th }}$ 2015. The instruments used was impinger for gasses parameters $\left(\mathrm{NO}_{2}, \mathrm{NH}_{3}, \mathrm{H}_{2} \mathrm{~S}, \mathrm{SO}_{2}\right.$, ozone, and hydrocarbon), and high volume sampler (HVS) for dust/ particle parameter. Method and measurement principle for all those 7 parameters was set by PP RI No. 41 Year 1999, wich were Griess-saltzman method for $\mathrm{NO}_{2}$, Indofenol method for $\mathrm{NH}_{3}$, Pararosanilin method for $\mathrm{H}_{2} \mathrm{~S}$, Metilen Blue method for Hidrogen Sulfida, Gravimetri method for dust, Neutral Buffer Potasium (NBKI) method for Ozone, and Khromatography Gas method for Hydrocarbon.

\section{Processing and data analysis}

a. All of the result of macroscopic, microscopic, and physiological parameters measurement beetwen the polluted and control plants was examined by ANOVA and continued with Duncan multiple range test $(\alpha=5 \%)$ if result showed a significant difference.

b. Comparison of plants tolerance level by RGR (Sulistijorini et al., 2008) and APTI (Singh et al.,1991).

Plants tolerance macroscopically done by observing the total increasing of leaf area (Sulistijorini et al., 2008). Relative Growth Rate (RGR) was calculated by the increasing of leaf area of each tree species with the formula:

$$
R G R=\frac{\ln L d(i) t a-\ln L d(i) t o}{t}
$$

Annotation:

Ld (i)ta = leaf areatypei-that the end of measurement

Ld (i)to $=$ leaf area type $i$-that the start of measurement

$\mathrm{t}=$ measurement interval (30 days)

Plants tollerance measured by RGR was analyzed by ANOVA, and if the result showed a significance difference then continued with Duncan test at $a=5 \%$. After that, scoring by the Duncan test result was done (modification of Dahlan in Sulistijorini et al., (2008)). Score 1 given if there was a significant difference and the average of polluted plants was lower than control. Score 2 given if the average of control and polluted plants was not significantly different; score 3 if there was a significant difference and the average of polluted plant was higher than control. Classification of plants tollerance determined by RGR score that included to tolerant was if the score $=3$, moderate tolerant if the score $=2$, and intolerant if score $=1$.

Plants tolerance measured by APTI was obtained by calculated the ascorbic acid content, chlorophyll, $\mathrm{pH}$, and relative water content based on APTI (Air Pollution Tolerance Index) formula (Singh et al., 1991):

$$
A P T I=\frac{A(T+P)+R}{10}
$$

Annotation:

$\mathrm{A}=$ total ascorbic acid $\left(\mathrm{mg} \mathrm{g}^{-1}\right)$ 1)

$$
\mathrm{P}=\text { leaf } \mathrm{pH} \quad \mathrm{R}=\text { leaf water content }(\%)
$$

APTI value of each plant types in polluted condition was compared to the table of sensitivity criteria and plants tolerance (Singh et al., 1991), that were: sensitive plant (<12), moderate (13$16)$, quite tolerant (17-20), and tolerant $(>20)$.

\section{c. Plant Carbohydrate Analysis}

Additional physiological parameter that were expected to affect tollerance level was total carbohydrate content, therefore correlation analysis was done beetwen macroscopic and physiological parameters to the total carbohydrate content in the leaf.

d. Correlation analysis of macroscopic and physiological parameters

Physiological condition of plants affected the macroscopic condition, therefore the correlation analysis beetwen macroscopic and physiological parameters was done to observed the most significant relation among those parameters. This result became a reference in determining a new modification of APTI formula by using linier regresion analysis.

\section{Synthesis}

Data and information of result analysis was arranged by level and plants tolerance aspects, so that the list of plants that were tolerant to air pollution was obtained.

\section{RESULT AND DISCUSSION}

\section{Air Quality}

Measurement result from some of the air quality parameters showed that pollution level in polluted area was higher than control (Table 2). However, the result showed that the air quality was still under the quality standard set by PP RI No. 40/1999. Based on measurement result, pollutan particle has a high consentration in polluted area $\left(9 \mu \mathrm{g} \mathrm{m}^{-3}\right)$ and its value was much higher than those in the control area $\left(<0,027 \mu \mathrm{g} \mathrm{m}^{-3}\right)$. Consentration of $\mathrm{NO}_{2}, \mathrm{SO}_{2}$, ammonia, ozone, and hydrocarbon 
in polluted area was higher than in control area, while $\mathrm{H}_{2} \mathrm{~S}$ and $\mathrm{CO}$ still in a very low consentration and has a same value as in the control area.

Particle concentration was the highest because most of the factories in industrial estate did industrial activities that produced particle, that is burning, milling and raw material smelting. In addition to industrial activities, high particle concentrations were also caused by motor vehicles, especially large vehicles passing by in industrial estate. Most large vehicles passing by in the industrial estate use diesel fuel emitting particle, $\mathrm{NO}_{2}$ and hydrocarbon pollutants. According to Fitter and Hay (1992), nitrogen oxide is a by-product of combustion arising from a combination of nitrogen and atmospheric oxygen. The main source of $\mathrm{NO}_{2}$ was combustion, the highest burning comes from motor vehicles. The high concentration of $\mathrm{NO}_{2}$ was also thought to be related to the high number of large vehicles passing through the measured areas and the burning results of some factories.

\section{Macroscopic Observation}

Based on the result, the increasing of leaf number and leaf area was not significantly different based on location of pollution, but generally the increasing number of leaf in polluted areas was higher than in control and the increasing of leaf area in polluted area was higher than control except for $P$. indicus and $S$. mahagoni (Table 3). The inhibition of plant growth caused by air pollution only take effect on $P$. indicus and S. mahagoni. This suggests that both plant was sensitive to air pollution even in a very low consentration.

Observations that show higher plant growth compared to these controls were inconsistent with Kovacs (1992) assertion that air pollution causes stunted plant growth due to inhibition of photosynthetic product intake to apical cells will lead to inhibition of cell division and elongation that affect the growth of leaf surface area. The decrease in chlorophyll content leads to a decrease in photosynthesis rate so that photosynthesis results were also reduced. This was influenced by three air pollutants suspected to affect the rate of increase in the number and extent of plant leaves in polluted areas are $\mathrm{NO}_{2}, \mathrm{SO}_{2}$, and particle.
Table 2. Measurement result of some air quality parameters

\begin{tabular}{|c|c|c|c|c|}
\hline Parameters & $\begin{array}{l}\text { Industrial } \\
\text { estates } \\
\text { (polluted) }\end{array}$ & $\begin{array}{l}\text { Resident } \\
\text { district } \\
\text { (control) }\end{array}$ & $\begin{array}{l}\text { Standard } \\
\text { quality* }\end{array}$ & Unit \\
\hline $\begin{array}{l}\text { Nitrogen } \\
\text { Oxide }\left(\mathrm{NO}_{2}\right)\end{array}$ & 0.014 & 0.005 & 400 & $\begin{array}{l}\mu \mathrm{g} \\
\mathrm{m}^{-3}\end{array}$ \\
\hline $\begin{array}{l}\text { Sulphur } \\
\text { Dioxide } \\
\left(\mathrm{SO}_{2}\right)\end{array}$ & 0.002 & $<0.001$ & 900 & $\begin{array}{l}\mu \mathrm{g} \\
\mathrm{m}^{-3}\end{array}$ \\
\hline $\begin{array}{l}\text { Ammonia } \\
\left(\mathrm{NH}_{3}\right)\end{array}$ & 0.087 & 0.038 & 17 & $\begin{array}{l}\mathrm{mg} \\
\mathrm{m}^{-3}\end{array}$ \\
\hline $\begin{array}{l}\text { Hydrogen } \\
\text { Sulfide }\left(\mathrm{H}_{2} \mathrm{~S}\right)\end{array}$ & $<0.01$ & $<0.01$ & 14 & $\begin{array}{l}\mathrm{mg} \\
\mathrm{m}^{-3}\end{array}$ \\
\hline Ozone $\left(\mathrm{O}_{3}\right)$ & 12 & 10 & 200 & $\begin{array}{l}\mu \mathrm{g} \\
\mathrm{m}^{-3}\end{array}$ \\
\hline $\begin{array}{l}\text { Carbon } \\
\text { Monoxide } \\
(\mathrm{CO})\end{array}$ & $<1000$ & $<1000$ & 30000 & $\begin{array}{l}\mu \mathrm{g} \\
\mathrm{m}^{-3}\end{array}$ \\
\hline $\begin{array}{l}\text { Hydrocarbon } \\
(\mathrm{HC})\end{array}$ & 2.96 & $<0.65$ & 160 & $\begin{array}{l}\mu \mathrm{g} \\
\mathrm{m}^{-3} \\
\end{array}$ \\
\hline Particle & 9 & $<0.027$ & 230 & $\begin{array}{l}\mu \mathrm{g} \\
\mathrm{m}^{-3}\end{array}$ \\
\hline
\end{tabular}

* Standard arality set hy PP RI No 41/1999

Nitrogen was absorbed root especially in the form of nitrate $\left(\mathrm{NO}_{3}{ }^{-}\right)$and ammonium $\left(\mathrm{NH}_{4}^{+}\right)$. In addition to the nitrogen contained in the growing medium, two nitrogen sources in industrial estates that allegedly could be utilized by plants are $\mathrm{NO}_{2}\left(0.014 \mathrm{\mu g} / \mathrm{m}^{3}\right)$ and $\mathrm{NH}_{3}\left(0.087 \mathrm{mg} / \mathrm{m}^{3}\right)$. Higher polluted values than controls indicated that this tree species were capable of using nitrogen derived from $\mathrm{NO}_{2}$ or $\mathrm{NH}_{3}$ in industrial estate. According to Rogers and Aneja (1980); Farquhar et al., (1980); Castro et al. ,(2006), stems and leaves can absorb nitrogen in the form of $\mathrm{NH}_{3}$. In addition, Nishimura et al. (1986); RowlandBamford and Drew (1988); Ammann et al., (1995) show that the leaves can absorb $\mathrm{NO}_{2}$ from the air.

Table 3 Leaf number, leaf area and leaf hue of each plant types

\begin{tabular}{|c|c|c|c|c|c|c|}
\hline \multirow{2}{*}{ Types of Plants } & \multicolumn{2}{|c|}{ Increase of leaf number } & \multicolumn{2}{|c|}{ Increase of leaf area $\left(\mathrm{cm}^{2}\right)$} & \multicolumn{2}{|c|}{ Leaf hue score } \\
\hline & Polluted & Control & Polluted & Control & Control & Polluted \\
\hline H. tiliaceus & 2.67 & 1.83 & 36.83 & 21.5 & 3 & 5 \\
\hline S. saman & 27.75 & 24.5 & 2.75 & 2.75 & 5.5 & 6 \\
\hline L. leucocephala & 5 & 1 & - & - & 6 & 3 \\
\hline P. indicus & 0 & 1 & 6 & 6.75 & 2.5 & 6 \\
\hline P. longifolia & 2 & 1.75 & 21.75 & 12.5 & 6 & 3.5 \\
\hline P. fragrans & 2.83 & 1.33 & 9.83 & 5.33 & 6 & 2.5 \\
\hline E. crysta-galli & 6.67 & 5.5 & 17.83 & 16.5 & 5 & 6 \\
\hline S. mahagoni & 0.5 & 1 & 6 & 16 & 5.5 & 6 \\
\hline C. junghuhniana & 3.33 & 2.3 & - & - & 3 & 6 \\
\hline A. auriculiformis & 4 & 7.5 & 5.75 & 2.83 & 6 & 5 \\
\hline
\end{tabular}

Nitrogen is a major component necessary for vegetative growth (Marschner, 1986 and Larcher, 1995 in Sulistijorini, 2008).
The measurement of leaf hue showed that each species has a different impacts of air pollution (Table 3). Leaf hue of of $L$. 
leucocephala, P. longifolia, P. fragrans, and A. auriculiformis species in polluted area was lower than control. Species of $L$. leucocephala, P. longifolia, and P. fragrans had a score of 2.5-3.5 (yellow green-light green-green) in polluted area. Result showed that leaf hue score of H. tiliaceus, S. saman, P. indicus, E. crista-galli, S. mahagoni, and C. junghuhniana in polluted area was higher than in control. Those species had a score of 5-6 (dark green) in polluted area.

Meitiyani (2003), states that contact with $\mathrm{SO}_{2}$ in low concentrations over long periods causes chronic damage characterized by yellowing of leaf color due to inhibition of chlorophyll formation mechanism. However, in A. auriculiformis the color difference between the polluted and control areas is not much different, ie the polluted area with a score of 5 (dark green) while the control with a score of 6 (dark green). This shows that air pollution has no significant effect, didn't give serious damage to A. auriculiformis plants and because pollutant concentration in polluted areas is not very high.

The results showed that the color scores of polluted leaf plants were higher than controls on plant species $H$. tilliaceus, S. saman, $P$. indicus, E. crista-galli, S. mahagoni, and C. junghuhniana. The type of plant has a score of 5-6 (dark green-dark green) in the polluted area. This indicates that the leaves affected by pollutants have a darker color. This dark color indicates that plant leaves can absorb and retain dense pollutants such as particles, especially hairy leaves (Gray and Deneke, 1978). This was in accordance with ambient air conditions in industrial estate that have high concentrations of particle pollutants, resulting in darker leaf color.

\section{Microscopic Observation}

Result of the analysis of variance showed that stomatal density was not significantly different based on the location of pollution but showed a significant difference based on the species of trees. Accordingly, the stomatal density of 10 species of sample trees in this research was varied between 182.5 to 939.5 per $\mathrm{mm}^{2}$ (Table 4). Stomatal density of P. indicus, P. longifolia, S. mahagoni, and $C$. junghuhniana in polluted area was higher than those in control. This plants respond to air pollutants by increasing its stomata. According to Gray and Deneke (1978), the type of plant with very high stomatal density has the potential as an agent to reduce air pollution.

Result of the analysis of variance indicated that leaf and palisade thickness were not significantly different by the location of pollution, while the species of trees only showed a significant difference on the leaf thickness. The observation result of this parameters indicated that there was a different responses on every species of trees. Leaf thickness of $H$. tiliaceus, $L$. leucocephala, P. longifolia, E. crista-galli, C. junghuhniana, and A. auriculiformis was higher in the polluted area (Table 4). Palisade thickness of all species of trees in polluted area was higher than control except for S. saman and P. indicus. Plants with higher leaf thickness and palisade thickness in polluted areas compared with controls showed plants tolerant to air pollution. In this case, $S$. saman and $P$. indicus are sensitive because both the thickness of the leaves and the palisade thickness in the polluted area are lower than the controls.

\section{Physiological Observation}

Result of analysis of variance indicated that there was a significant difference in the species of trees, but the location of pollution was not significanly different. The result of the research showed that the species of trees that had a higher ascorbic acid content in polluted area than in control was $H$. tiliaceus, L. leucocephala, P. indicus, P. longifolia, C. junghuhniana, and $A$. auriculiformis. Whereas the species of $S$. saman, $P$. fragrans, E. crista-galli, and S. mahagoni had a lower ascorbic acid content in polluted area than in control (Table 5). Plants with ascorbic acid content in polluted areas higher than control areas, they were included in tolerant plants. This was in accordance with the statement of Lima et al., 2000 and Rai et al., 2013, that plants are tolerant of air pollution have high ascorbic acid content because ascorbic acid has a function as an anti oxidant or a powerful reductor that can prevent oxidation reactions. In polluted areas, the highest permissible level of ascorbic acid is $L$. leucocephala, while the lowest is $P$. fragrans. This suggests that L. leucocephala has a high tolerance level for pollutants because of the high ascorbic acid content.

Analysis result showed that the chlorophyll content was not significantly different based on the species of trees, but significantly different based on location of pollution. Chlorophyll content in polluted area in almost all of the species was declining except for $P$. longifolia, $P$. fragrans and $C$. junghuhniana, while the A. auriculiformis was constant (Table 5). This is consistent with Carter and Knapp (2001) statement, that contaminants can induce chlorophyll reduction.

Result of the analysis of variance of this parameter indicated that the $\mathrm{pH}$ of leaf exctract was significantly different based on the species of trees but not significantly different based on location. Trees in polluted area has an acid $\mathrm{pH}$, which was in the range of 5-7, while in control area showed a higher $\mathrm{pH}$ with a range of 67. This is due to exposure to SOx, NOx, and other acidproducing pollutants derived from emissions from industrial estates, giving a $\mathrm{pH}$ change to acidic leaves, low $\mathrm{pH}$ leaf extracts showed a good correlation to air pollution and also inhibited photosynthesis in plants (Yan-Ju and Hui, 2008; Thakar and Mishra, 2010). Species with a high $\mathrm{pH}$ number in polluted area was H. tiliaceus, S. saman, L. leucocephala, P. indicus, E. crista-galli, S. mahagoni, and C. junghuhniana (Table 5).

Analysis result showed that both location and species of trees did not gave significant difference to water content parameter. The average value of relative water content in polluted area was lower than in control (Table 5). In polluted area, the highest water content was found in $S$. saman and the lowest was in $P$. fragrans. In control area, the highest was in $P$. indicus while the lowest was in $S$. saman. Higher water content in industrial estates responds to the normal functioning of biological processes in plants (Meerabai et al., 2012), which occur in $S$. saman, S. mahagoni, and C. junghuhniana. 
Table 4 Stomatal density, leaf thickness, and palisade thickness of each plant types

\begin{tabular}{lllllll}
\hline \multirow{2}{*}{ Types of Plants } & \multicolumn{2}{l}{ Stomatal density } & \multicolumn{2}{l}{ Leaf thickness } & \multicolumn{2}{l}{ Palisade thickness } \\
\cline { 2 - 7 } & Control & Polluted & Control & Polluted & Control & Polluted \\
\hline H. tiliaceus & 575.2 & 504.6 & 139.7 & 188.6 & 46.7 & 60.7 \\
\hline S. saman & 836.6 & 664.9 & 188 & 126.8 & 95.6 & 54.4 \\
\hline L. leucocephala & 237.2 & 186.9 & 145.2 & 180 & 42.8 & 67.9 \\
\hline P. indicus & 182.5 & 311.1 & 166.2 & 133.6 & 65.9 & 37.4 \\
\hline P. longifolia & 315.9 & 489.8 & 119.8 & 156.7 & 21.6 & 44.3 \\
\hline P. fragrans & 407.7 & 358.2 & 167.3 & 158.7 & 47 & 60.2 \\
\hline E. crysta-galli & 454.9 & 424.5 & 267.1 & 290.2 & 70.7 & 92.9 \\
\hline S. mahagoni & 542.7 & 743.2 & 157.5 & 152.5 & 33.1 & 43.5 \\
\hline C. junghuhniana & 864.5 & 939.5 & 656.2 & 725.9 & 71.6 & 95.9 \\
\hline A. auriculiformis & 466.2 & 387 & 152.5 & 189.6 & 40 & 46.7
\end{tabular}

Table 5 Ascorbic acid content, Chlorophyll, pH, and water content of each plant types

\begin{tabular}{|c|c|c|c|c|c|c|c|c|}
\hline \multirow[t]{2}{*}{ Types of Plant } & \multicolumn{2}{|c|}{$\begin{array}{l}\text { Ascorbic acid } \\
\left(\mathrm{mg} \mathrm{g}^{-1}\right)\end{array}$} & \multicolumn{2}{|c|}{$\begin{array}{l}\text { Chlorophyll } \\
\left(\mathrm{mg} \mathrm{g}^{-1}\right)\end{array}$} & \multicolumn{2}{|l|}{$\mathrm{pH}$} & \multicolumn{2}{|c|}{ Water content $(\%)$} \\
\hline & Polluted & Control & Polluted & Control & Polluted & Control & Polluted & Control \\
\hline S. saman & 8.08 & 10.51 & 6.15 & 11.10 & 6.8 & 6.7 & 67.36 & 58.64 \\
\hline L. leucocephala & 15.54 & 15.50 & 4.60 & 6.40 & 6.9 & 6.5 & 66.54 & 68.96 \\
\hline P. indicus & 8.30 & 3.37 & 8.90 & 14.05 & 6.8 & 6.2 & 66.21 & 77.82 \\
\hline P. fragrans & 4.33 & 6.65 & 3.50 & 7.00 & 5.8 & 6.1 & 53.89 & 59.84 \\
\hline E. crysta-galli & 5.21 & 10.94 & 6.30 & 15.05 & 6.8 & 7.3 & 66.64 & 68.75 \\
\hline S. mahagoni & 10.25 & 12.70 & 9.15 & 14.35 & 6.5 & 6 & 61.53 & 60.5 \\
\hline C. junghuhniana & 6.54 & 6.32 & 4.35 & 2.35 & 6.3 & 6.2 & 61.63 & 59.67 \\
\hline A. auriculiformis & 13.61 & 16.01 & 3.70 & 3.70 & 5.4 & 6.4 & 61.04 & 66.53 \\
\hline
\end{tabular}

\section{Comparison of Plants Tolerance Level Between RGR and APTI}

Based on the calculation result, tolerance level obtained based on APTI and RGR value was quite significantly different (Table 6). Table 5 showed that the most significant result of tolerance level difference was in $P$. fragrans and $S$. mahagoni species. Species $P$. fragrans included to tolerant plants based on RGR but come under a sensitive type based on APTI. On the contrary, $S$. mahagoni was included to intolerant based on RGR but included to tolerant type based on APTI. Determination of tolerant plants based on APTI (Singh et al. 1991) was really influenced by ascorbic acid parameter. Based on APTI, if the content of ascorbic acid was high then the plants would considered as tolerant type, like L. leucocephala species, and contrarily if ascorbic acid content was low, plants would be included to sensitive type, for example $P$. fragrans species. APTI formulation showed that the alteration of ascorbic acid gave the best effect rather than other parameters like total chlorophyll, leaf exctract $\mathrm{pH}$, and leaf water content.

\section{Analysis of Total Carbohydrate Content}

Analysis of correlation between carbohydrate content with macroscopic and physiological parameters was done to discovered the effect of carbohydrate level to those parameters.
The result indicated that the correlation of total carbohydrate to other parameters was insignificant $(p>0.05)$. However, the highest correlation was with RGR (correlation $=0.492$ ). Analysis result of linier regression also showed a positive correlation between RGR and total carbohydrate content. The equation obtained was $y=0.078 x+0.81$ with $R^{2}=0.492$, which means that the escalation of RGR number by about $49.2 \%$ was affected by the total carbohydrate content of the leaf, and the rest was affected by other parameters.

Based on the calculation result, total carbohydrate content as an additional parameter had a highest correlation number compared to other parameters, that equal to 0.429 with $p=0.053$ (credibility level approaching 95\%). It indicated that carbohydrate gave a big impact to the tolerance level of plants. In consequences, APTI formulation put forward by Singh et al. (1991) needs to be modified because of the unsynchronicity between the RGR number with the quality of every physiological parameters in it. Furthermore, based on the result of correlation analysis, total carbohydrate content as a physiological parameter had a big role toward RGR.

The result was matched the research of Seyyednejad et al. (2011) which found that plants with a high sugar content was a species that were tolerant toward air pollution due to the polymer of 
Table 6 Comparison of plants tolerance level based on RGR and APTI

\begin{tabular}{|c|c|c|c|c|c|c|}
\hline \multirow{2}{*}{ Type of Plants } & \multicolumn{2}{|l|}{ RGR } & \multirow{2}{*}{$\begin{array}{l}\text { Score } \\
* *\end{array}$} & \multirow{2}{*}{$\begin{array}{l}\text { Tolerance level } \\
\text { (RGR) }\end{array}$} & \multirow{2}{*}{ APTI score } & \multirow{2}{*}{$\begin{array}{l}\text { Tolerance level } \\
\text { (APTI) }\end{array}$} \\
\hline & Polluted & Control & & & & \\
\hline H. tiliaceus & $1.228 \mathrm{~b}^{*}$ & $0.717 \mathrm{c}$ & 3 & Tolerant & 19.16 & Quite tolerant \\
\hline S. saman & $0.094 \mathrm{a}$ & $0.092 \mathrm{a}$ & 2 & Medium & 17.20 & Quite tolerant \\
\hline L. leucocephala & $* * *$ & $* * *$ & $* * *$ & $* * *$ & 24.53 & Tolerant \\
\hline P. indicus & $0.200 \mathrm{a}$ & $0.225 \mathrm{ab}$ & 1 & Intolerant & 19.65 & Quite tolerant \\
\hline P. longifolia & $0.725 \mathrm{a}$ & $0.417 \mathrm{ab}$ & 3 & Tolerant & 15.86 & Moderate \\
\hline P. fragrans & $0.328 \mathrm{a}$ & $0.178 \mathrm{ab}$ & 3 & Tolerant & 9.42 & Sensitive \\
\hline E. crysta-galli & $0.594 \mathrm{a}$ & $0.550 \mathrm{bc}$ & 3 & Tolerant & 13.48 & Moderate \\
\hline S. mahagoni & $0.200 \mathrm{a}$ & $0.533 \mathrm{abc}$ & 1 & Intolerant & 22.19 & Tolerant \\
\hline C. junghuhniana & $* * *$ & $* * *$ & $* * *$ & $* * *$ & 13.12 & Moderate \\
\hline A. auriculiformis & $0.192 \mathrm{a}$ & $0.094 \mathrm{a}$ & 2 & Medium & 18.48 & Quite tolerant \\
\hline
\end{tabular}

* Values in each column with the same letter arenot significantly different according to Duncan Multiple Range Test at a=5\%

** Based on Dahlan modification (1995)

*** RGR measurement was not done due to technical problems in measuring the increasing of leaf area

fructose that could help the tolerant species under the unfavorable condition. For example, the ryegrass plant was undergo the increasing of fructans content when exposed to a momentarily air pollution in Sao Paolo (Brazil) (Moretto et al., 2009). Sandrinet al. (2013) reported that the enhancement of fructans particularly in the root of Lollium multiflorum L. at noon of spring and fall season, consist when the temperature was high, the light intensity was low, and the concentration of pollutant was at the highest level. In those condition, photosynthesis process was well stimulated so that it accumulated a higher concentration of sugar. The fructans (polyfructosylsucrose) itself was a major carbohydrate storage in the plants. The synthesis of fructans in the leaf was correlated with the synthesis of sucrose and translocation along with the sucrose metabolism in the stem and root. Fructans was instrumental to the plant growth under an unfavorable condition, such as in the condition of polluted air, because it has a role as an absorbent of reactive oxygen or indirectly stimulated the mecanism of antioxydative defense.

\section{Analysis of Correlation Between Macroscopic and Physiological Parameters}

The analysis of correlation was done to macroscopic parameter that consist of the increasing of leaf number, leaf hue, leaf thickness, RGR 1 (RGR number of the first one month interval observation), RGR 2 (RGR number of the second one month interval observation), and RGR (RGR number of the two months interval observation), as well as the physiological parameter that consist of total carhodyrate, ascorbic acid, chlorophyll, $\mathrm{pH}$, and water content. The result of correlation analysis showed the most significant correlation occured between RGR 1 and the total carbohydrate, with the correlation value of 0.717 (categorized as strong correlation) with $p=0.045$. However, the correlation between RGR 1 and other parameters tend to be low, with the ascorbic acid, chlorophyll, and $\mathrm{pH}$ included to low correlation category, and water content included to a very low correlation category.
Correlation analysis result between RGR 1 and physiological parameter showed that ascorbic acid, as the main parameter in determining tolerance level in plants, evidently had a low correlation with RGR 1 (correlation= 0.287). This result was in accordance with Sulistijorini et al. (2008) which reported that the tolerance based on RGR was not affected by the ascorbic acid of leaf, as in Lagerstroemia speciosa L. (included to tolerant type) that had a lowest ascorbic acid content compared to other seven species. Chlorophyll parameter (correlation= 0.390 ) also did not brough any significant difference to RGR 1 . This result was in a contrary with Carter and Knapp (1991) which found that pollutants could induced chlorophyll reduction, as well as Carter and Knapp (1991) which reported that the presence of air pollution could induce necrosis and chlorosis that involved the mecanism of chlorophyll damage. Pandey and Agrawal (1994) proved that plants in urban areas that relatively polluted had a lower chlorophyll content and significantly different to those in uncontaminated areas. Leaf water content as an element in APTI formula also could not able to describe therole of water content in the defense mecanism from the exposured of pollutants. As seen on the correlation analysis result, water content only had correlation level by $-0,046$. The increasing of water content in polluted plants was allegedly because of water uptake from the ground and the transpiration of plants was in a equilibrium state. This presumption was supported by Taiz and Zeiger (2002) which stated that water availability on the leaf was affected by ability of root absorption and plants transpiration. The $\mathrm{pH}$ parameter also insignificantly correlated with RGR 1 (correlation= 0.293). In accordance to previous calculation, total carbohydrate as the additional parameter had a highest correlation number compared to other parameters, with the value of 0.717 and $\mathrm{p}=0.045$ (credibility level 95\%).

The result matched the previous estimation and calculation that total carbohydrate gave the biggest effect to RGR compared to physiological parameter in APTI formula put forward by Singh et al. (1991). The RGR 1 had the most significant correlation also caused by the sampling time to physiological analysis that were coincide with the second observation of plant growth. 
Classification of plants tolerance by RGR had a strength because RGR can describe plants ability to adapt in polluted condition. Mecanism of plants adaptation to air pollutants can be measured based on the change of physiological condition. Therefore, determination of tolerance level of plants was based on the correlation between physiological parameter and RGR 1. Result of multiple linier regresion analysis obtained a new APTI formulation as follows:

Modified APTI $=1,05 K-0,287 A-0,002 T-0,997 P+0,18 R$

Annotation:

$\mathrm{K}=$ Total carbohydrate $(\%)$

$\mathrm{A}=$ Total ascorbic acid $(\mathrm{mg}$ $\left.\mathrm{g}^{-1}\right)$

$\mathrm{T}=$ Total chlorophyll $\left(\mathrm{mg} \mathrm{g}^{-1}\right) \quad \mathrm{P}=$ leaf $\mathrm{pH} \quad \mathrm{R}=$ leaf water content $(\%)$

Scoring and classification of tolerance level was refers to Dahlan modification (1995). Plants tolerance level shown at Table 7 and the result indicated that tolerance level between RGR 1 and modified APTI was same, with $P$. longifolia, $P$. fragrans, E. cristagalli, and C. junghuhniana classified as tolerant species, $H$. tiliaceus, S. saman and A. auriculiformis included to moderate tolerant, along with L. leucocephala, P. indicus, and S. mahagoni included to intolerant.

\section{CONCLUSION}

Comparison of plants tolerance level based on APTI and RGR showed a different results. Classification of plants tolerance based on RGR had a strength because RGR can describe adaptation ability of plants in polluted conditions. The results showed that total carbohydrate as an additional parameter of APTI affected the level of tolerance by $49.2 \%$ and also the most sensitive parameter to air pollutants rather than others physiological parameters, thus modified the APTI formulation and changed the classification of plants tolerance. Result of modified APTI if $\mathrm{A}=$ ascorbic acid content, $\mathrm{T}=$ total chlorophyll, $\mathrm{P}=$ leaf $\mathrm{pH}, \mathrm{R}=$ water content, and $\mathrm{K}=$ total carbohydrate is: Modified APTI $=1.05 \mathrm{~K}-0.287 \mathrm{~A}-$ $0.002 T-0.997 P+0.18 R$. Results showed that the tolerant plants were Polyalthia longifolia, Polyalthia fragrans, Erythrina crista-galli, and Casuarina junghuhniana; moderate tolerance were Hibiscus tiliaceus, Samanea saman and Acacia auriculiformis; and intolerant were Leucaena leucocephala, Pterocarpus indicus, and Swietenia mahagoni.

\section{REFERENCES}

Arnon. 1949. Copper enzymes in isolated chloroplast: polyphenol oxidase in Beta vulgaris. Plant Physiol 24:1-15.

Bora M, Joshi N. 2014. A study on variation in biochemical aspect of different tree species with tolerance and performance index. The BioscanAn Intl Quarterly J Life Sci 9:59-63.
Carter GA, Knapp AK. 2001. Leaf optical properties in higher plants: Linking spectral characteristics to stress and

Table 7 Plants tolerance based on RGR 1 and modified APTI

\begin{tabular}{|c|c|c|c|c|c|c|c|}
\hline \multirow[b]{2}{*}{$\begin{array}{l}\text { Type of } \\
\text { Plants }\end{array}$} & \multicolumn{2}{|c|}{ RGR 1} & \multirow{2}{*}{$\begin{array}{l}\text { Sco } \\
\text { re } \\
* *\end{array}$} & \multicolumn{2}{|c|}{$\begin{array}{l}\text { Modified } \\
\text { APTI }\end{array}$} & \multirow{2}{*}{$\begin{array}{l}\text { Sco } \\
\text { re } \\
* *\end{array}$} & \multirow[b]{2}{*}{$\begin{array}{l}\text { Tolerance } \\
\text { level }\end{array}$} \\
\hline & $\begin{array}{l}\text { Poll } \\
\text { uted }\end{array}$ & $\begin{array}{l}\text { Co } \\
\text { ntr } \\
\text { ol }\end{array}$ & & $\begin{array}{l}\text { Poll } \\
\text { uted }\end{array}$ & $\begin{array}{l}\text { Contr } \\
\text { ol }\end{array}$ & & \\
\hline $\begin{array}{l}\mathrm{H} . \\
\text { tiliaceus }\end{array}$ & $\begin{array}{l}0.99 \\
b^{*}\end{array}$ & $\begin{array}{l}0.6 \\
9 \mathrm{~b}\end{array}$ & 2 & $\begin{array}{l}6.24 \\
a b^{*}\end{array}$ & $\begin{array}{l}8.58 \\
a b\end{array}$ & 2 & Moderate \\
\hline S. saman & $\begin{array}{l}0.12 \\
\mathrm{a}\end{array}$ & $\begin{array}{l}0.1 \\
1 \mathrm{a}\end{array}$ & 2 & $\begin{array}{l}7.30 \\
a b\end{array}$ & $\begin{array}{l}6.80 \\
a b\end{array}$ & 2 & Moderate \\
\hline $\begin{array}{l}\text { L. } \\
\text { leucocepha } \\
\text { la }\end{array}$ & $* * *$ & $* * *$ & $* * *$ & $\begin{array}{l}4.18 \\
a b\end{array}$ & $\begin{array}{l}10.06 \\
b c\end{array}$ & 1 & Intolerant \\
\hline P. indicus & $\begin{array}{l}0.12 \\
\mathrm{a} \\
\end{array}$ & $\begin{array}{l}0.2 \\
8 \\
a b\end{array}$ & 1 & $\begin{array}{l}5.16 \\
a b\end{array}$ & $8.82 \mathrm{~b}$ & 1 & Intolerant \\
\hline $\begin{array}{l}P . \\
\text { longifolia }\end{array}$ & $\begin{array}{l}1.03 \\
\mathrm{~b}\end{array}$ & $\begin{array}{l}0.6 \\
7 \\
\mathrm{ab} \\
\end{array}$ & 3 & $\begin{array}{l}9.48 \\
\mathrm{~b}\end{array}$ & $\begin{array}{l}9.10 \\
b c\end{array}$ & 3 & Tolerant \\
\hline$P$. fragrans & $\begin{array}{l}0.24 \\
\mathrm{a}\end{array}$ & $\begin{array}{l}0.0 \\
7 \\
\mathrm{ab}\end{array}$ & 3 & $\begin{array}{l}5.68 \\
a b\end{array}$ & $4.92 \mathrm{a}$ & 3 & Tolerant \\
\hline $\begin{array}{l}\text { E. crysta- } \\
\text { galli }\end{array}$ & $\begin{array}{l}1.02 \\
b\end{array}$ & $\begin{array}{l}0.1 \\
3 \\
a b\end{array}$ & 3 & $\begin{array}{l}6.53 \\
b\end{array}$ & $\begin{array}{l}10.59 \\
b c\end{array}$ & 3 & Tolerant \\
\hline $\begin{array}{l}\text { S. } \\
\text { mahagoni }\end{array}$ & $\begin{array}{l}0.27 \\
\mathrm{a}\end{array}$ & $\begin{array}{l}0.8 \\
7 \\
a b\end{array}$ & 1 & $\begin{array}{l}5.94 \\
a b\end{array}$ & $6.70 \mathrm{~b}$ & 1 & Intolerant \\
\hline $\begin{array}{l}\text { C. } \\
\text { junghuhni } \\
\text { ana }\end{array}$ & $* * *$ & $* * *$ & $* * *$ & $\begin{array}{l}8.82 \\
a b\end{array}$ & $6.40 \mathrm{~b}$ & 3 & Tolerant \\
\hline $\begin{array}{l}\text { A. } \\
\text { auriculifor } \\
\text { mis }\end{array}$ & $\begin{array}{l}0.15 \\
a\end{array}$ & $0 \mathrm{a}$ & 2 & $\begin{array}{l}2.84 \\
\mathrm{a}\end{array}$ & $3.80 \mathrm{a}$ & 2 & Moderate \\
\hline
\end{tabular}

* Values in each column with the same letter are not significantly different according to Duncan Multiple Range Test at $\alpha=5 \%$

** Based on Dahlan modification (1995)

*** RGR measurement was not done due to technical problems in measuring the increasing of leaf area

chlorophyll concentration. American J Botany 84:677-684.

Castro AI, Stulen FS, Posthumus LJ, Kok de. 2006. Changes in growth and nutrient uptake in Brassica oleraceae exposed to atmospheric ammonia. Ann Bot. 97: 121-131.

Dahlan EN. 1995. Effects of Air pollutants on plant leaves. Final Report for Osaka Gas Foundation. Bogor: IPB.

Fitter AH, Hay RKM. 1998. Fisiologi Lingkungan Tanaman. Yogyakarta: Gajah Mada University Press.

Grey GW, Deneke FJ. 1978. Urban Forestry. New York: John Willey and Sons.

Krakatau Industrial Estate Cilegon [KIEC]. 2014. Laporan hasil pengujian udara ambien dan debu jatuh di Kawasan 
Industri. Laboratorium Lingkungan Krakatau Steel Cilegon.

Kovacs. 1992. Trees as biological indicators. In: Biological indicators in environmental protection. Kovacs, M. (ed), Ellis Horwood, New York.

Kozlowski TT, Mudds JB. 1975. Response of plants to air pollution. Academic Press, New York.

Lima JS, Fernandes EB, Fawcett WN. 2000. Mangifera indica and Phaseolus vulgaris in the bioindicator of air pollution in Bahia, Brazil. Ecotoxicol Environ. Saf. 46(3): 275-278.

Liu YJ, Ding H. 2008. Variation in air pollution tolerance index of plant near a steel factory: implications for landscapeplant species selection for industrial area. Wseas Trans Enviro Develop 4:24-32.

Masuko T, Minami A, Iwasaki N, Majima T, Nishimura SI, Lee YC. 2005. Carbohydrate analysis by a phenol-sulfuric acid method in microplate format. Analytic Biochem339:69-72.

Meerabai G, Venkata Ramana C, Rasheed M. 2012. Effect of industrial pollutants on Physiology of Cajanus cajan (L.)Fabaceae. Int J Environ Sci. 2(4): 1889-1894.

Moretto R, Sandrin CZ, Itaya NM, Domingos M, FigueiredoRibeiro RCL. 2009. Fructan variation in plants of Loliummultiflorum ssp. italicum 'Lema' (Poaceae) exposed to an urban environment contaminated by high ozone concentrations. In: Benkeblia N, Shiomi N.(Eds.). Proceedings of the Sixth International Fructan Symposium. Dynamic Biochemistry, Process Biotechnology and Molecular Biology 3(Special Issue 1), pp.1-9.

Nishimura HT, Hayamishu Y, Yanasigawa. 1986. Reduction of NO2 to NO by rush and other Plants. Environ Sci Technol. 20: 413-416.

Oguntimehin I, Kondo H, Sakugawa H. 2010. The use of sunpatiens (Impatiens spp.) as a bioindicator of some simulated air pollutants-using an ornamental plant as bioindicator. Chemosphere81:273-281.

Pandey J, Agrawal M. 1994. Evaluation of air pollution phytotoxicity in seasonally dry tropical urban environment using three woody perennials. New Phytol126: 53-64.

Rachmat RS. 2014. Protes masalah pencemaran lingkungan, warga Ciwandan duduki pintu gerbang pemkot Cilegon [online]. [download 2014 August 27]. Available at: http://www.beritacilegon.com/index.php/beritacilegon/cilegon-raya/5391-perotes-masalahpencemaran-lingkungan,-warga-ciwandan-duduki-

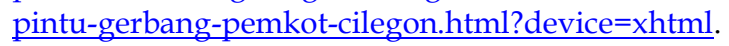

Rai PK, Panda LLS, Chutia BM, Singh MM. 2013. Comparative assessment of air pollution tolerance index (APTI) in the industrial (Rourkela) and non industrial area (Aizawl) of India: An eco-management approach. African J EnvSci Tech 7:944-948.
Reiss C. 1993. Experiment in plant physiology: Part I, plant biochemistry, determination of ascorbic acid content of cabbage. p 1-7.

Rogers HH, Rogers VP, Aneja. 1980. Uptake of atmospheric ammonia by selected plant species. Environ Exp Bot. 20: 251-257.

Rowland-Bamford AJ, Drew MC. 1988. The influence of plant nitrogen status on NO2 uptake, NO2 assimilation and on the gas exchange characteristics of barley plants exposed to atmospheric NO2. J Exp Bot. 9: 1287-1297.

Salama HMH, Al-Rumaih MM, Al-Dosary MA. 2011. Effect of Riyadh cement industry pollutions on some physiological and morphological factors of Datura innoxiaMill. Plant. Saudi J Bio Sci 18:227-237.

Sandrin CZ, Ribeiro ACF, Delitti WBC, Domingos M. 2013. Short-term changes of fructans in ryegrass (Lolium multiflorum 'Lema') in response to urban air pollutants and meteorological conditions. Ecotoxico Environ Saf 96:80-85.

Sass JE. 1951. Botanical microtechnique. The Iowa State College press, Iowa.

Sen DN, Bhandari MC. 1978. Ecological and water relation to two Citrullusspp, In: Althawadi, A,M, (Ed,), Indian Arid Zone, Environ, Physiol, Ecol, Plants pp. 203-228.

Seyyednejad SM, Niknejad M, Koochak H. 2011. A review of some different effect of air pollution on plants. J Environ Sci 5:302-309.

Singh SK, Rao DN. 1983. Evaluation of plants for their tolerance to air pollution, In Procsymp on air pollution control held at IIT Delhi pp. 218-224.

Singh SK, Rao DN, Agrawal M, Pandey J, Narayan D. 1991. Air Pollution Tolerance Index of Plant. J Environ Mgmt 32:4555.

Sulistijorini, Mas'ud ZA, Nasrullah N, Bey A, Tjitrosemito S. 2008. Tolerance level of roadside trees to air pollutants based on relative growth rate and air pollution tolerance index. Hayati J Biosci15:123-129.

Taiz L, Zeiger E. 2002. Plant Physiology. 3rd. ed. Sinauer Pub, Masschusetts.

Udayana C. 2004. Toleransi spesies pohon tepi jalan terhadap pencemaran udara di simpang susun Jakarta (Jakarta Interchange) Cawang, Jakarta Timur [graduate thesis]. Bogor (ID): Bogor Agricultural University. 94 p.

Yan-Ju L, Hui D. 2008. Variation in air pollution tolerance index of plant near a steel factory; implication for landscapeplant species selection for industrial areas. Environ Dev. 1(4): 24-30. 